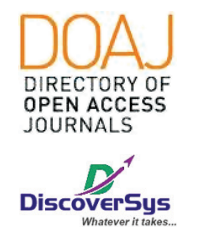

Published by DiscoverSys

\section{Karakteristik kasus faringitis akut di Rumah Sakit Umum Daerah Wangaya Denpasar periode Januari - Desember 2015}

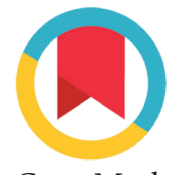

CrossMark

\author{
Darryl Abdi Triadi, ${ }^{1 *}$ I Made Sudipta
}

\section{ABSTRACT}

Background: Acute pharyngitis is an infection of the pharynx caused by viruses or bacteria, which is characterized by the presence of a sore throat, exudate, hyperemia, fever, lymph nodes enlargement of the neck, and malaise. The most common etiology are the germs of Streptococci $\beta$-haemolyticus, Streptococcal viridans, and Streptococci pyogenes. It can also be caused by viral infections such as influenza and adenovirus. Acute pharyngitis can be transmitted through contact by nasal or droplet infection of people suffering pharyngitis.

Aim: The study aimed to report acute pharyngitis in the Wangaya General Hospital in the period January - December 2015.

Method: This study was an observational study using a descriptive cross sectional design for patients with acute pharyngitis in the Wangaya General Hospital in the period January - December 2015.
Result and Conclusion: Proportion of acute pharyngitis patients based on age at Wangaya General Hospital were the highest in the age group 0-14 years as many as 47 people (55.9\%). The lowest proportion is in the age group $>50$ years, 16 people (19\%). By its sex proportion, the highest was among women, 48 people (57.2\%) as against 36 people (42.8\%) for men. Based on clinical symptoms proportion in Wangaya General Hospital, throat pain as many as 57 people $(67.9 \%)$, followed by difficulty of swallowing as many as $47(55.9 \%)$, fever 19 (22.6\%), vomiting 18 (21.4\%), malaise $17(20.2 \%)$, lymph nodes enlargement $13(15.5 \%)$, and those with a headache $4(4.8 \%)$

Keywords: Acute pharyngitis, ARI, droplets

Cite This Article: Triadi, D.A., Sudipta, I.M. 2020. Karakteristik kasus faringitis akut di Rumah Sakit Umum Daerah Wangaya Denpasar periode Januari - Desember 2015. Intisari Sains Medis 11(1): 245-247. D0I: 10.15562/ism.v11i1.349

\title{
ABSTRAK
}

Faringitis akut adalah infeksi pada faring yang disebabkan oleh virus atau bakteri, yang ditandai oleh adanya nyeri tenggorokan, faring eksudat dan hiperemis, demam, pembesaran limfanodi leher dan malaise. Penyebab terbanyak radang ini adalah kuman golongan Streptokokus ß-haemolyticus, Streptoccocus viridans dan Streptoccocus pyogenes. Penyakit ini juga dapat disebabkan oleh infeksi virus seperti virus influenza dan adenovirus. Faringitis akut dapat menular melalui kontak dari sekret hidung dan ludah (droplet infection) dari orang yang menderita faringitis. Tujuan: untuk mengetahui gambaran tentang penyakit faringitis akut di Rumah Sakit Umum Daerah (RSUD) Wangaya Denpasar periode Januari-Desember 2015.

Metode: Penelitian ini merupakan penelitian observasional yang menggunakan rancangan desktiptif cross sectional terhadap penderita penyakit faringitis akut di RSUD Wangaya Denpasar periode Januari Desember 2015.
Hasil danSimpulan: Proporsi penderita Faringitis Akutberdasarkan umur di RSUD Wangaya Denpasar yang tertinggi dijumpai pada pada kelompok umur 0-14 tahun, yaitu 47 orang $(55,9 \%)$. Proporsi terendah terdapat pada kelompok umur $>50$ tahun, yaitu 16 orang (19,0\%). Proporsi penderita Faringitis Akut berdasarkan jenis kelamin di RSUD Wangaya Denpasar yang tertinggi adalah pada perempuan yaitu 48 orang $(57,2 \%)$. Sedangkan pada laki-laki yaitu 36 orang (42,8\%). Proporsi penderita Faringitis Akut berdasarkan gejala klinis yang dialami di RSUD Wangaya yang tertinggi adalah nyeri tenggorok sebanyak 57 orang $(67,9 \%)$, diikuti sulit menelan sebanyak 47 orang $(55,9 \%)$, demam 19 orang $(22,6 \%)$, muntah 18 orang $(21,4 \%)$, malaise 17 orang ( 20,2\%), kelenjar limfa bengkak 13 orang $(15,5 \%)$, dan yang disertai nyeri kepala 4 orang $(4,8 \%)$
Darryl Abdi Triadi, Program Stud Pendidikan Dokter, Fakultas Kedokteran Universitas Udayana, Denpasar, Bali darryl3012@gmail.com

Diterima: 10-11-2018 Disetujui: 06-03-2020 Diterbitkan: 26-03-2020
Kata kunci: Faringitis akut, ISPA, droplet

Cite Pasal Ini: Triadi, D.A., Sudipta, I.M. 2020. Karakteristik kasus faringitis akut di Rumah Sakit Umum Daerah Wangaya Denpasar periode Januari - Desember 2015. Intisari Sains Medis 11(1): 245-247. D0l: 10.15562/ism.v11i1.349 


\section{PENDAHULUAN}

Salah satu penyakit yang paling sering terjadi pada sebagian besar orang adalah faringitis. Faringitis muncul dengan gejala bervariasi, diantaranya nyeri tenggorokan tiba-tiba, demam, sakit kepala, limfadenitis, dan kadang-kadang nyeri perut, mual, kelelahan, dan atau ruam. Tanda penyakit tersebut meliputi demam yang bisa mencapai $>38,5^{\circ} \mathrm{C}$ dan tampilan hiperemis pada dinding saluran nafas. Gejala atipikal yang sering muncul pada anakanak, seperti sakit perut atau muntah.

Beberapa diagnosis banding harus diperhatikan untuk mengetahui penyebab penyakit tersebut, mulai dari infeksi, inflamasi, traumatik, atau neoplastic. Namun, sebagian besar gejala ini berasal dari virus atau bakteri. Faringitis akut sudah mencapai angka kejadian sekitar 2\% dari keluhan pasien dewasa dan

Tabel 1 Distribusi frekuensi penderita faringitis akut berdasarkan umur di RSUD Wangaya Denpasar periode Januari Desember 2015

\begin{tabular}{lcc}
\hline & \multicolumn{2}{c}{ Jumlah } \\
\cline { 2 - 3 } Umur (tahun) & $\mathbf{f}$ & $\%$ \\
\hline $0-14$ & 45 & 53,6 \\
$15-49$ & 23 & 27,4 \\
$>50$ & 16 & 19,0 \\
Jumlah & 84 & 100 \\
\hline
\end{tabular}

Tabel 2 Distribusi frekuensi penderita faringitis akut berdasarkan jenis kelamin di RSUD Wangaya Denpasar periode Januari Desember 2015

\begin{tabular}{lcc}
\hline & \multicolumn{2}{c}{ Jumlah } \\
\cline { 2 - 3 } Jenis Kelamin & $\mathbf{f}$ & $\%$ \\
\hline Perempuan & 48 & 57,2 \\
Laki-laki & 36 & 42,8 \\
Jumlah & 84 & 100,0 \\
\hline
\end{tabular}

Tabel 3 Distribusi frekuensi penderita faringitis akut berdasarkan gejala klinis di RSUD Wangaya Denpasar periode Januari Desember 2015

\begin{tabular}{lcc}
\hline & \multicolumn{2}{c}{ Jumlah } \\
\cline { 2 - 3 } Gejala Klinis & $\mathbf{f}$ & $\%$ \\
\hline Nyeri tenggorok & 57 & 67,9 \\
Sulit menelan & 47 & 55,9 \\
Demam & 19 & 22,6 \\
Muntah & 18 & 21,4 \\
Malaise & 17 & 20,2 \\
Pembesaran KGB & 13 & 15,5 \\
Nyeri kepala & 4 & 4,8 \\
\hline
\end{tabular}

6\% untuk pasien anak-anak setiap tahunnya (lebih dari 1 juta visitasi). Group A $\beta$-hemolytic streptococcus (GABHS) adalah patogen yang paling sering ditemui, dan menyebabkan faringitis akut mencapai 5-15\% pada orang dewasa serta $15-36 \%$ pada anakanak. Dari pemaparan tersebut, penulis mengeksplorasi gambaran kejadian faringitis akut di Rumah Sakit Umum Daerah (RSUD) Wangaya.

\section{METODE}

Penelitian ini merupakan penelitian observasional yang menggunakan rancangan deskriptif potong lintang selama periode Januari-Desember 2015 dengan teknik total sampling. Sampel dari penelitian ini merupakan 84 orang pasien faringitis akut yang menjalani rawat jalan dan rawat inap di RSUD Wangaya Denpasar periode Januari - Desember 2015. Data yang didapat diolah secara manual, dianalisa secara deskriptif dan disajikan dalam bentuk tabel distribusi frekuensi untuk menggambarkan faringitis akut dengan variabel-variabel yang mempengaruhinya. Data yang dikumpulkan berasal dari data sekunder rekam medis pasien mengenai umur, jenis kelamin, dan gejala klinis faringitis akut.

\section{HASIL}

Berdasarkan sajian pada Tabel 1 terlihat bahwa proporsi umur penderita tertinggi dijumpai pada kelompok umur 0-14 tahun, yaitu 47 orang (55,9\%). Proporsi terendah terdapat pada kelompok umur $>50$ tahun, yaitu 16 orang (19\%). Tabel 2 menyajikan proporsi jenis kelamin tertinggi pada perempuan yaitu 48 orang $(57,2 \%)$ sedangkan 36 orang $(42,8 \%)$ pada laki-laki. Selain itu, Tabel 3 memperlihatkan bahwa proporsi gejala klinis penderita faringitis akut terbanyak adalah nyeri tenggorok sebanyak 57 orang $(67,9 \%)$, diikuti kesulitan menelan sebanyak 47 orang $(55,9 \%)$, demam 19 orang $(22,6 \%)$, muntah 18 orang $(21,4 \%)$, malaise 17 orang $(20,2 \%)$, pembesaran kelenjar getah bening (KGB) 13 orang $(15,5 \%)$, dan nyeri kepala 4 orang $(4,8 \%)$.

\section{DISKUSI}

\section{Gambaran Penderita Faringitis Akut Berdasarkan Umur dan Jenis Kelamin}

Faringitis merupakan penyakit umum pada dewasa dan anak-anak. National Ambulatory Medical Care Survey dan National Hospital Ambulatory Medical Care Survey telah mendokumentasikan antara 6,2 - 9,7 juta kunjungan anak-anak dengan faringitis ke klinik dan UGD (Unit Gawat Darurat) setiap tahun, dan lebih dari 5 juta kunjungan orang dewasa per tahun. ${ }^{3}$ Frekuensi munculnya faringitis lebih sering pada populasi anak-anak. Kira-kira 
$15-30 \%$ kasus faringitis pada anak-anak usia sekolah dan $10 \%$ kasus faringitis pada orang dewasa.

\section{Gambaran Penderita Faringitis Berdasarkan Gejala Klinis}

Gejala-gejala yang timbul pada faringitis akut bergantung pada mikroorganisme yang menyertainya. Faringitis akut yang disebabkan bakteri mempunyai gejala nyeri kepala yang hebat, demam atau menggigil, malaise, nyeri menelan, muntah dan mungkin batuk tapi jarang timbul. ${ }^{2}$ Faringitis akibat infeksi bakteri Streptococcus group A dapat diperkirakan dengan menggunakan Centor criteria, yaitu demam, limfaadenopati pada anterior servikal, eksudat pada tonsil, tidak ada batuk. ${ }^{2,6-9}$ Faringitis yang disebabkan virus biasanya mempunyai gejala nyeri tenggorokan yang parah dan dapat disertai dengan batuk, suara serak dan nyeri substernal. Demam, menggigil, malaise, mialgia, dan sakit kepala juga dapat terjadi. Lalu, gejala pada faringitis fungal adalah nyeri tenggorokan dan nyeri menelan. Pada pemeriksaan tampak plak putih di orofaring dan mukosa faring lainnya hiperemis.

Infeksi virus dan bakteri dapat ditransmisikan melalui media ludah, yang menyebar saat batuk (drooplet infection) atau melalui tangan atau barang pribadi penderita yang terkontaminasi. Masa inkubasi radang tenggorok rata-rata antara 2-5 hari. Masa inkubasi virus berkisar antara 3 hari hingga 2 minggu. Infeksi virus influenza bersifat menular dan sangat mudah tersebar. Pada kondisi flu, peradangan berlangsung sekitar tiga sampai sepuluh hari. Umumnya, peradangan terasa lebih berat pada pagi hari dan berupa self-limiting disease. Gejala lain bisa berupa rasa lemas, anorexia, demam, dan batuk. Sakit tenggorokan juga ditemukan pada infeksi virus lainnya seperti infeksi varicella dan measless. Tubuh memerlukan daya tahan untuk membangun antibodi untuk menghancurkan virus-virus tersebut. Infeksi mononucleosis disebabkan virus Epstein-Barr, dan membutuhkan waktu yang lebih lama untuk sembuh. Virus ini mempengaruhi sistem limpa sehingga menyebabkan pembesaran pada amandel dan muncul bercak putih pada permukaannya. Selain itu, juga terjadi pembengkakan pada pembuluh di leher. ${ }^{10}$

Penelitian Lubis et al. (2018) berhasil menunjukkan bakteri yang berhasil dikultur dari 23 sampel jaringan pasien dengan penyakit saluran nafas atas. Untuk bakteri gram positif aerob, ada $S$. aureus dan S. epidermidis, sedangkan untuk bakteri gram negatif aerob ada Klebsiella pneumonia, K. oxytoca, dan Proteus vulgaris. Untuk bakteri anaerob, hanya gram positif Peptostreptococcus yang terdeteksi dan hanya dalam satu sampel. Tidak ada pertumbuhan bakteri anaerob lain yang diamati. S. aureus dan S. epidermidis sensitif terhadap antibiotik berikut ini: cefotaxime, ceftazidime, cefoperazone, levofloxacin, ciprofloxacin, doksisiklin, vancomycin (semuanya 100\%); dan tahan terhadap tetrasiklin, penisilin, dan amoksisilin. ${ }^{3}$

\section{SIMPULAN}

Proporsi penderita faringitis akut berdasarkan umur di RSUD Wangaya Denpasar yang tertinggi dijumpai pada pada kelompok umur 0-14 tahun dan proporsi terendah terdapat pada kelompok umur $>50$ tahun. Proporsi penderita faringitis akut berdasarkan jenis kelamin di RSUD Wangaya Denpasar yang tertinggi dialami pada perempuan. Proporsi penderita faringitis akut berdasarkan gejala klinis yang dialami di RSUD Wangaya yang tertinggi adalah nyeri tenggorok, diikuti sulit menelan, demam, muntah, malaise, pembesaran KGB, dan disertai nyeri kepala.

\section{DAFTAR PUSTAKA}

1. Rusmarjono dan Bambang Hermani. Bab IX Nyeri Tenggorok. Dalam: Efiaty AS, Nurbaiti I, Jenny B, dan Ratna DR. Buku Ajar Ilmu Kesehatan Telinga Hidung Tenggorok Kepala dan Leher. Edisi ke-6. Jakarta; 2007: pp. 212-218.

2. Miriam TV, Nadhia C, dan Aneela NH. Pharyngitis. In: A Peer-Reviewed Journal of the American Academy of Family Physician, 2004. State University of New York Downstate Medical Center, Brooklyn, New York (online); 2004. Available from: http://www.aafp.org/afp/2004/0315/ p1465.html [Accessed: 26 Des 2016].

3. Lubis, A., Munir, D., Nursiah, S., Kusumawati, R., Eyanoer, P. 2018. The aerobic-anaerobic bacteria pattern and its sensitivity pattern in chronic rhinosinusitis patients, in Medan, Indonesia. Bali Medical Journal 7(1): 51-55. DOI: 10.15562/bmj.v7i1.801

4. Shulman ST, Tanz RR, Gerber MA. Streptococcal pharyngitis. In: Stevens DL, Kaplan EL, eds. Streptococcal infections: clinical aspects, microbiology, and molecular pathogenesis. New York: Oxford University Press; 2000: pp. 76-101.

5. Alan LB. Acute Pharyngitis: Primary Care. The New England Journal of Medicine, 2011; 344:205-211.

6. Moirangthem, A., Gurung, K. 2013. Bacteriological Analysis and Its Antibiogram Profile of Pharyngitis Cases from the Patients Attending Referral Hospital, Sikkim, India. Bali Medical Journal 2(1): 10-13.

7. Nigro JFAN, Nigro CEND, Marone SAM, Voegels RL, Microbiology Of Maxillary And Ethmoid Sinuses in Patients with Chronic Rhinosinusitis Submitted to Functional Endoscopic Sinus Surgery. Barzillian Journal Otorhinolaryngology, 2006;76(2);217 - 221.

8. Li J, Wu Yanqiao W, Li Xiaoming, Bin Di, Wang L. Distribution And Drug Sensitivity Test Of Bacteria Of Patients On Chronic Rhinosinusitis With Or Without Nasal Polyps. PubMed. 2016;30(2):115-8

9. Bachert C, Pawankar R, Zhang L, Bunnag C, Fokkens WJ, Hamilos DL, et al. ICON: Chronic Rhinosinusitis. World Allergy Organ J. 2014;7(1): 25.

10. Hakim, A., Khan, A. 2014. Problematika penyakit pribumi bagi para wisatawan asing di kota Manado. Intisari Sains Medis 1(1): 24-28. DOI: 10.15562/ism.v1i1.92

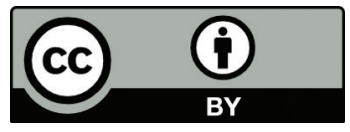

This work is licensed under a Creative Commons Attribution 